\title{
Amelioration of sandy soils in drought stricken areas through use of Ca-bentonite
}

\author{
O. Semalulu, M. Magunda and D.N. Mubiru
}

National Agricultural Research Laboratories - Kawanda, P. O. Box 7065, Kampala, Uganda

Author for correspondence: o.semalulu@gmail.com

\begin{abstract}
Soil moisture shortage is a major limiting factor to agricultural production in eastern Africa, in view of increased drought incidences and seasonal rainfall variability. This study evaluated the potential for Ca-bentonite (a 2:1 clay mineral) as a possible amendment for increased moisture retention by sandy soils in drought stricken/prone areas in Uganda. The study was conducted both in the greenhouse at NARL-Kawanda and in the field, Nakasongola district. In the greenhouse $\left(27-30^{\circ} \mathrm{C}\right)$, Ca-bentonite was mixed with a sandy soil in proportions of $0,5,10,15$ and $20 \%$ by weight, replicated three times. The mixtures were watered to field capacity (30\% water) then maize (Longe V) planted and left to grow for 5 weeks without any additional water application. Under field conditions, Ca-bentonite was applied on sandy soils in the drought-prone Lwabiyata sub county, Nakasongola district in central Uganda. Treatments included: Ca-bentonite applied at $0,1.25$ and $2.5 \mathrm{t} \mathrm{ha}^{-1}$; DAP at $0,62.5$ and $125 \mathrm{~kg} \mathrm{ha}^{-1}$; urea at 0 and $60 \mathrm{~kg} \mathrm{ha}^{-1}$; and farmyard manure (FYM) at $0,1.25$ and $2.5 \mathrm{t} \mathrm{ha}^{-1}$, arranged in a randomised block design with three replicates. Under greenhouse conditions, Ca-bentonite application significantly $(P<0.05)$ increased the soil moisture retention, $\mathrm{pH}, \mathrm{N}, \mathrm{P}, \mathrm{Ca}$ and $\mathrm{Mg}$ content, and subsequently, maize dry matter yield. Averaged over 2 seasons, field application of $2.5 \mathrm{t} \mathrm{Ca-bentonite} \mathrm{ha}^{-1}$ increased maize grain yield by $37.6 \%$. Yields were significantly $(P<0.05)$ higher $(79.8$ to $82.0 \%$ above the control) where bentonite $\left(2.5 \mathrm{t} \mathrm{ha}^{-1}\right)$ was combined with DAP $\left(62.5 \mathrm{kgha}^{-1}\right.$ or FYM $\left(2.5 \mathrm{tha}^{-1}\right)$. The results suggest that Cabentonite has potential as a soil amendment for moisture conservation, neutralising acidity, and improving $\mathrm{N}, \mathrm{P}, \mathrm{Ca}$ and $\mathrm{Mg}$ content in sandy soils, and consequently support crop growth and yield. Thus calcium bentonite presents a possible amelioration for sandy soils of low fertility in drought stressed environments. It is thus a promising technology for climate change adaptation in drought prone areas.
\end{abstract}

Key words: Climate change adaptation, drought mitigation, moisture stress, soil moisture conservation, soil fertility management 


\section{Introduction}

Calcium bentonite is a naturally occurring $2: 1$ clay mineral which is known to hold water many times its own weight. According to Czaban et al. (2013), when applied to a sandy soil, bentonite particles bond with those of sand and thus improve the structure and water holding properties of sand. The improved structure holds nutrients, air and water in a structure that is ideally suited to plant roots. Previous studies suggest that to be effective, calcium bentonite should be dug into the root zone. Studies in Thailand recommended bentonite application rate of $10 \%$ of the soil volume in the greenhouse while for field application, $5 \mathrm{~kg}$ of calcium bentonite per $16 \mathrm{~m}^{2}$ is recommended, dug into a depth of 10 to $30 \mathrm{~cm}$ (Czaban et al. (2013).

The benefits of using calcium bentonite in agriculture have been reported in Thailand, China, Australia and South Africa among others. Noble et al. (2004) and Suzuki et al. (2007) demonstrated that introducing clay-based materials such as bentonite significantly and persistently improves the productivity of degraded, light-textured soils, more so in presence of an organic amendment. In Thailand, bentonite significantly increased rice grain yields and reduced the risk of crop failure during drought (IWMI, 2010). Sorghum forage biomass yields increased by sixfold following bentonite application. The increased soil quality persisted for at least 3 years.

Berthelsen et al. (2005) reported significant increase in crop biomass and yields following bentonite application on light textured soils. The yield increase was attributed to increased water holding capacity, nutrient availability and reduced nutrient loss. In Australia, Sacchi (2010) observed increased soil cation exchange capacity, exchangeable $\mathrm{Ca}, \mathrm{Mg}, \mathrm{K}$ and plant available water following bentonite application. Sacchi also observed that application of bentonite at rates of above $80 \mathrm{t} \mathrm{ha}^{-1}$ had a detrimental impact on soil structure leading to reduced yields.

Despite the reported promising results, scanty information on bentonite use exists for sub Saharan Africa, yet limitations due to moisture stress and soil fertility decline to crop performance are widespread in this region. In Uganda, calcium bentonite is mined in Hoima district and marketed by the Knights Mining Company and most of it is exported. However, there is inadequate information about its potential to support crop growth within the country. Therefore, the objectives of this study were to establish the effect of calcium bentonite on soil properties, evaluate its effect on maize growth and yield, and propose possible use guidelines for its use in Uganda.

\section{Materials and methods}

The study consisted of a greenhouse and a field study. Conducted at the National Agricultural Research Laboratories Institute (NARLI) of the National Agricultural Research Organization (NARO), the greenhouse study was meant to gather preliminary data about the product prior to field activities. Finely ground calcium bentonite was obtained from Knights Mining Company in Hoima district in western Uganda. The material was tested for $\mathrm{pH}$, organic matter (OM), phosphorus, $\mathrm{Ca}, \mathrm{Mg}, \mathrm{K}$ and total $\mathrm{N}$ using standard methods (Okalebo et al., 1993). To study the effect of bentonite on the characteristics of sand and soil as well as plant growth, $100 \mathrm{~kg}$ of sand and a medium textured, low fertility soil were sampled 
at 0 to $30 \mathrm{~cm}$ depth from Tororo and Mbale districts, respectively. The soil and sand samples were dried for 3 days at $47^{\circ} \mathrm{C}$. Soil was then ground. The sand and soil were sieved through a $2 \mathrm{~mm}$ sieve and analysed for moisture content, $\mathrm{pH}$, organic matter (OM), phosphorus, exchangeable $\mathrm{Ca}^{2+}, \mathrm{Mg}^{2+}, \mathrm{K}^{+}$, total $\mathrm{N}$ and particle size distribution using standard methods (Okalebo et al., 1993).

In the greenhouse, twenty, $3-\mathrm{kg}$ samples of both the air-dried soil and sand were weighed in polythene bags. Calcium bentonite was added to the soil materials at $0,150,300,450$ and $600 \mathrm{~g}$ bentonite per $3 \mathrm{~kg}$ soil, representing a bentonite to soil percentage of: $0,5,10,15$ and $20 \%$, respectively. The soil-bentonite and sandbentonite mixtures were agitated thoroughly, then transferred to plastic buckets, perforated at the bottom. Deionised water $(1 \mathrm{~L})$ was added to each bucket containing the soil-bentonite and sand-bentonite mixtures, representing approximately $30 \%$ moisture (wt). The mixtures were stirred using a stirring rod and left to stand in a greenhouse at 27 to $32^{\circ} \mathrm{C}$, for 3 days. They were then stirred and sampled using soil cores measuring $5.0 \mathrm{~cm}$ diameter and $5.1 \mathrm{~cm}$ height. The mixtures were left in a greenhouse at 27 to $32^{\circ} \mathrm{C}$ for 28 days, and sampled every after one week (7 days). No more water was added to the mixtures during the entire 4-week period. The samples were dried at $105^{\circ} \mathrm{C}$ for moisture determination. At the end of 4 weeks, a sample of each mixture was collected for determination of $\mathrm{pH}, \mathrm{OM}$, phosphorus, exchangeable $\mathrm{Ca}, \mathrm{Mg}, \mathrm{K}$ and total $\mathrm{N}$ (Okalebo et al., 1993).

In the maize growth experiment, twenty, 3-kg samples of the soil/bentonite and sand/bentonite mixtures were prepared as described above. To each mixture, one litre of distilled water was added and left to stand in a greenhouse $\left(27\right.$ to $32^{\circ} \mathrm{C}$ ) for 3 days. Maize (Longe 5, 2 seeds) was planted in each bucket. Water $(50 \mathrm{ml})$ was added to each bucket and the maize left to grow for 35 days (5 weeks) under greenhouse conditions. No additional water was added to the maize plants. This was intended to assess the extent to which bentonite addition could improve water retention by soil or sand and support maize growth under moisture stress. The maize plants were harvested at 5 WAP by cutting at each plant $1 \mathrm{~cm}$ above the soil surface, weighed and oven dried at $78^{\circ} \mathrm{C}$ for 3 days for dry matter (biomass) determination.

For the field experiments, trials were planted in Lwabiyata sub county, located $1^{\circ} 30^{\prime} 20^{\prime \prime} \mathrm{N}$ and $32^{\circ} 22^{\prime} 41^{\prime \prime} \mathrm{E}$ in the northern part of Nakasongola district (Mugisha et al., 2011). Nakasongola district lies in the central plateau of Uganda, at an altitude between 1,000 and 1,400 $\mathrm{m}$ above sea level (Rwabwoogo, 2002). The district lies in the pastoral rangelands agro-ecological zone within the cattle corridor area. It is characterised by undulating landscape with most low lying areas found towards L. Kyoga in the north. The vegetation type is characterised by open deciduous savannah woodland with short grasses. The district experiences high temperatures ranging from a 25 to a $35^{\circ} \mathrm{C}$ during the dry season. It receives low and unreliable rainfall that ranges from 500 to $1000 \mathrm{~mm}$ per annum. There are two rainy seasons: the main season from March to May with peak in April and a second season from September to December with a modest peak in November. Evaporation exceeds rainfall by a factor of about 6 during the dry months from June to August (GOU, 2004). Lwabiyata sub county is located near L. Kyoga, and is characterised by 
sandy soils with moderate to poor fertility. Crop yields in the area are frequently affected by drought.

A trial was established in this area with the following treatments : a control (where nothing was applied), bentonite at $2.5 \mathrm{tha}$ ${ }^{1}$, bentonite $\left(2.5 \mathrm{t} \mathrm{ha}^{-1}\right)+$ DAP $(62.5 \mathrm{~kg}$ $\left.\mathrm{ha}^{-1}\right)$, bentonite $\left(2.5 \mathrm{tha}^{-1}\right)+$ FYM $(2.5 \mathrm{t}$ $\left.\mathrm{ha}^{-1}\right)$, bentonite $\left(1.25 \mathrm{tha}^{-1}\right)+\operatorname{DAP}(62.5$ $\left.\mathrm{kg} \mathrm{ha}^{-1}\right)+$ FYM $\left(1.25 \mathrm{tha}^{-1}\right)$ and DAP $\left(125 \mathrm{~kg} \mathrm{ha}^{-1}\right)+$ urea $\left(60 \mathrm{~kg} \mathrm{ha}^{-1}\right)$. These treatments were applied randomly and replicated three times in plot sizes of $10 \mathrm{~m}$ by $10 \mathrm{~m}$. Bentonite, farmyard manure and DAP were surface broadcast and incorporated into the 0 to $10 \mathrm{~cm}$ soil layer, using a hand rake. Urea was top dressed on the treatments which had DAP when maize was knee high. Maize (Longe 5) was grown during the March-June (2013A) then September - December (2013B) seasons and harvested for grain yield. A sample of maize grain was taken to the laboratory, weighed, oven-dried for 3 days at $78^{\circ} \mathrm{C}$ and weighed again. The per cent loss in weight was used to compute the maize grain yield, expressed on a hectare basis. Soil was sampled (0$30 \mathrm{~cm}$ ) at planting and at harvest, air-dried and analysed for $\mathrm{pH}$, organic matter (OM), phosphorus, exchangeable $\mathrm{Ca}^{2+}, \mathrm{Mg}^{2+}, \mathrm{K}^{+}$, total $\mathrm{N}$ and particle size distribution using standard methods (Okalebo et al., 1993).

\section{Data analysis}

Data were processed using Microsoft Excel and statistically analysed using GenStat package, Version 3.2. Significant differences between means were determined at a $95 \%$ Confidence level and means separated using the standard error of difference (sed) procedure. Two means were declared as significantly different when the difference between them was greater than twice the sed value.

\section{Results}

\section{Characteristics of the bentonite and soils}

Table 1 presents the characteristics of calcium bentonite and the soils used in the study. The Tororo sand and Mbale soil were used in the greenhouse while Nakasongola soil was one where the field trials were conducted. Bentonite had clay texture, with nearly neutral $\mathrm{pH}(\mathrm{pH}$ 6.9), low in organic matter $(\mathrm{OM})$ and $\mathrm{N}$ contents, high in $\mathrm{Ca}$ and $\mathrm{Mg}$, with moderate Mehlich III extractable P and low K content. All the three soils were high in sand, although sand was lower for the Mbale soil, which had 21\% clay. All three soils had lower $\mathrm{pH}$ values than bentonite with the Mbale soil having the lowest value (Table 1). Organic matter $(\mathrm{OM}), \mathrm{N}, \mathrm{P}, \mathrm{Ca}, \mathrm{Mg}$ and $\mathrm{K}$ were also lower for the three soils compared to those of bentonite, with the values much lowest for Tororo sand.

\section{Bentonite and soil moisture}

Moisture content of the mixtures increased significantly $(\mathrm{P}<0.05)$ with the amount of calcium bentonite added to potted soil materials, levelling off between 10 to $15 \%$ of bentonite, application for both the medium textured soil and sandy soil materials (Fig. 1). At 1 WAP, moisture content increased with increasing amount of bentonite added (Fig. 1). The trend was quadratic, with moisture content levelling off at $15 \%$ bentonite for soil and $10 \%$ bentonite for sand. However, the moisture content for soil was not significantly $(\mathrm{P}>0.05)$ different from that of sand amended with the same amount of bentonite. At 4 WAP, un-amended soil had a significantly $(\mathrm{P}<0.05)$ higher moisture content than un-amended sand. Moisture content of soil and sand amended with 5\% 
were not significantly different from the control. Sandy soil amended with $10 \%$ or more bentonite contained more moisture at $4 \mathrm{WAP}$, than the medium textured soil amended with the same amount of bentonite (i.e. 9.3 vs 3.6, 10.4 vs 7.9 and 11.0 vs $7.8 \%$ moisture for the 10,15 and $20 \%$ bentonite treated sand mixtures, respectively).

\section{Selected chemical properties soil materials}

Table 2 presents the effects of bentonite application on Mbale soil and Tororo sand materials during the 4 weeks period. At a given level of bentonite application, the $\mathrm{pH}$ for sand was significantly $(\mathrm{P}<0.05)$ higher than that of soil. Application of 5\% bentonite significantly $(\mathrm{P}<0.05)$ increased the $\mathrm{pH}$ by 3.5 and $11.1 \%$, for soil and sand, respectively. Higher bentonite rates maintained higher $\mathrm{pH}$ values in the sandy and not in the medium textured soil medium. Nitrogen was deficient in both the soil and sand, but with soil N slightly higher than that of sand at all levels of bentonite applied. Application of bentonite up to $10 \%$ had no significant effect on soil $\mathrm{N}$ content. Higher rates of bentonite (15 $\& 20 \%$ ) decreased soil nitrogen content significantly $(\mathrm{P}<0.05)$. On the other hand application of bentonite at $5 \%$ on the Ndeficient sand significantly $(\mathrm{P}<0.05)$ increased the $\mathrm{N}$ content. At higher rates of bentonite, the sand $\mathrm{N}$ content although significantly higher than the control, did not significantly differ from that at $5 \%$ bentonite.

There was a significant $(\mathrm{P}<0.05)$ increase in Mehlich III (Mehlich, 1984) extractable $\mathrm{P}$ with addition of $5 \%$ bentonite for both the soil and sand. A further significant $(\mathrm{P}<0.05)$ increase in Mehlich III extractable $\mathrm{P}$ was observed for higher rates of bentonite applied. Potassium 


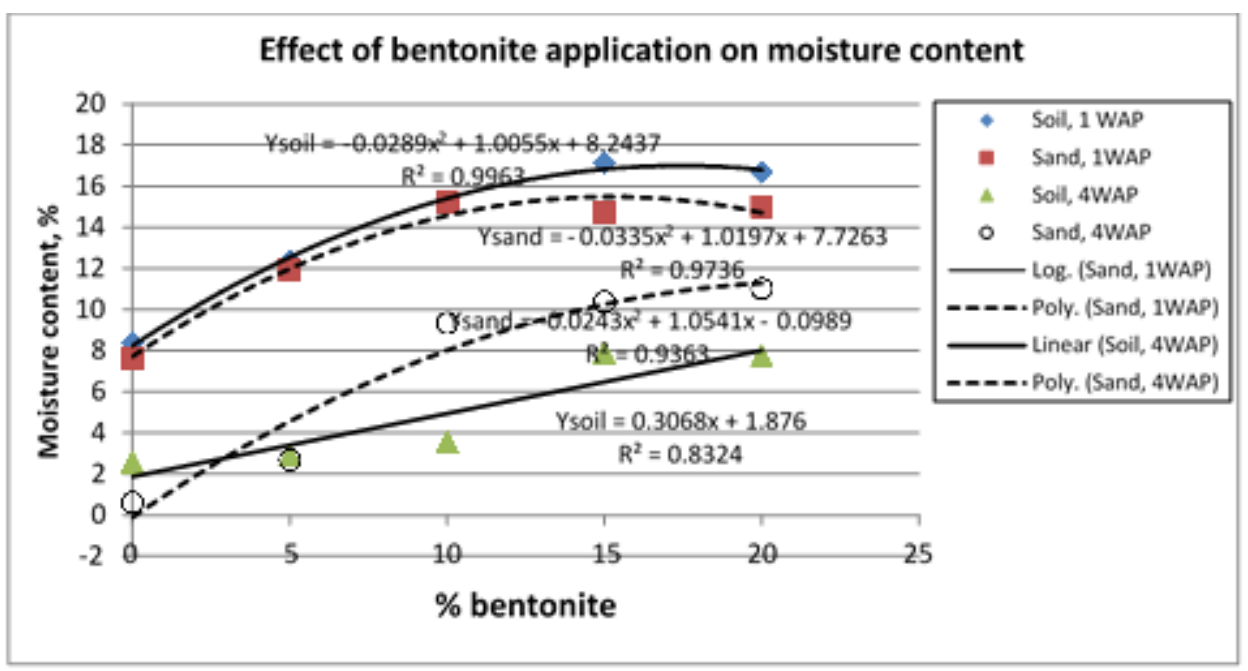

Figure 1. Effect of bentonite application on the moisture content of different soil types.

content was higher for soil than sand (170.9 vs $\left.83.7 \mathrm{mgkg}^{-1}\right)$. Bentonite application had no significant $(\mathrm{P}>0.05)$ effect on the $\mathrm{K}$ content of the soil and sand. There was a significant $(\mathrm{P}<0.05)$ increase in Mehlich III extractable Ca with addition of $5 \%$ bentonite for both the soil and sand. A significant $(\mathrm{P}<0.05)$ progressive increase in $\mathrm{Ca}$ content of both soil and sand was observed for higher rates of bentonite applied. Mehlich III extractable $\mathrm{Mg}$ increased significantly $(\mathrm{P}<0.05)$ on addition of $5 \%$ bentonite for both the soil and sand. A significant $(\mathrm{P}<0.05)$ progressive increase $\mathrm{Mg}$ content of both soil and bentonite was observed at higher rates of bentonite applied. The $\mathrm{Ca} / \mathrm{Mg}$ ratio for soil was lower than that of sand (3.02 vs 9.53). Bentonite application significantly $(\mathrm{P}<0.05)$ decreased the $\mathrm{Ca} / \mathrm{Mg}$ ratio for both soil and sand. The decrease increased with increasing rates of bentonite.

\section{Maize dry matter yield}

Dry matter yield increased significantly $(\mathrm{P}<0.05)$ with the amount of bentonite applied (Fig. 2), with values peaking off at $10 \%$ bentonite for sand and $15 \%$ at for soil mixtures. The data show that for sand treated with 15 and $20 \%$ bentonite, dry matter yield was not different from that at $10 \%$ bentonite. For a given level of bentonite treatment, dry matter was significantly $(\mathrm{P}<0.05)$ higher for the sand than the soil mixtures.

\section{Maize grain yield}

Results for the field evaluation of calcium bentonite on maize are presented in Table 3. During 2013A maize grain yields were not affected by any of the treatments applied. In 2013B which was a better season, application of bentonite $(2.5 \mathrm{~kg}$ $\mathrm{ha}^{-1}$ ) alone increased maize grain yields from 718 to $1306 \mathrm{kgha}^{-1}$, an increment of $82 \%$ (although this was not significantly (P>0.05) different from the control). Combining bentonite with DAP or manure resulted in even higher and significant $(\mathrm{P}<0.05)$ yields over the control. Averaged over two seasons, bentonite application alone improved maize grain yields from 689 to $948 \mathrm{~kg} \mathrm{ha}^{-1}$, an increase of $37.6 \%$. This increase was not significantly ( $P>0.05)$ over the control. However, 
Table 2. Effect of bentonite application on selected soil and sand chemical properties at 4 weeks after planting

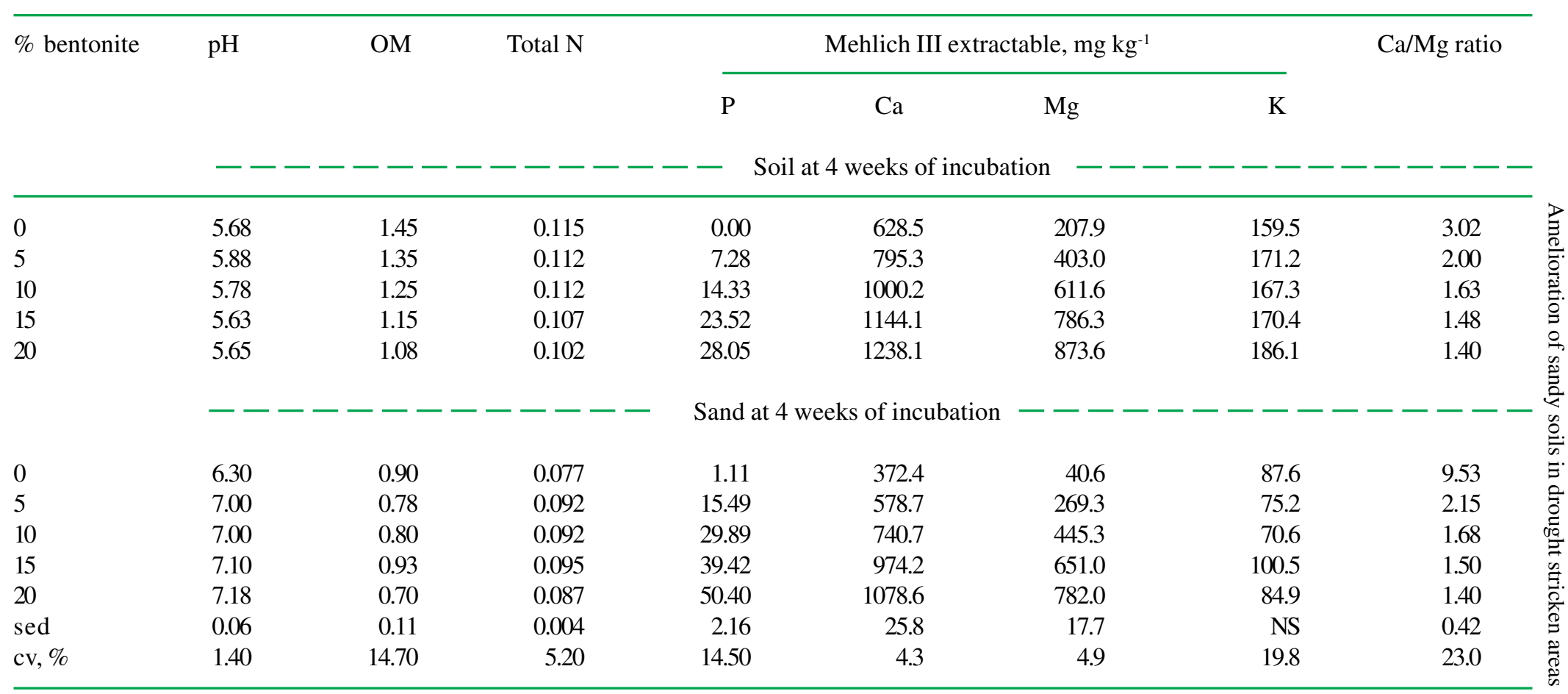




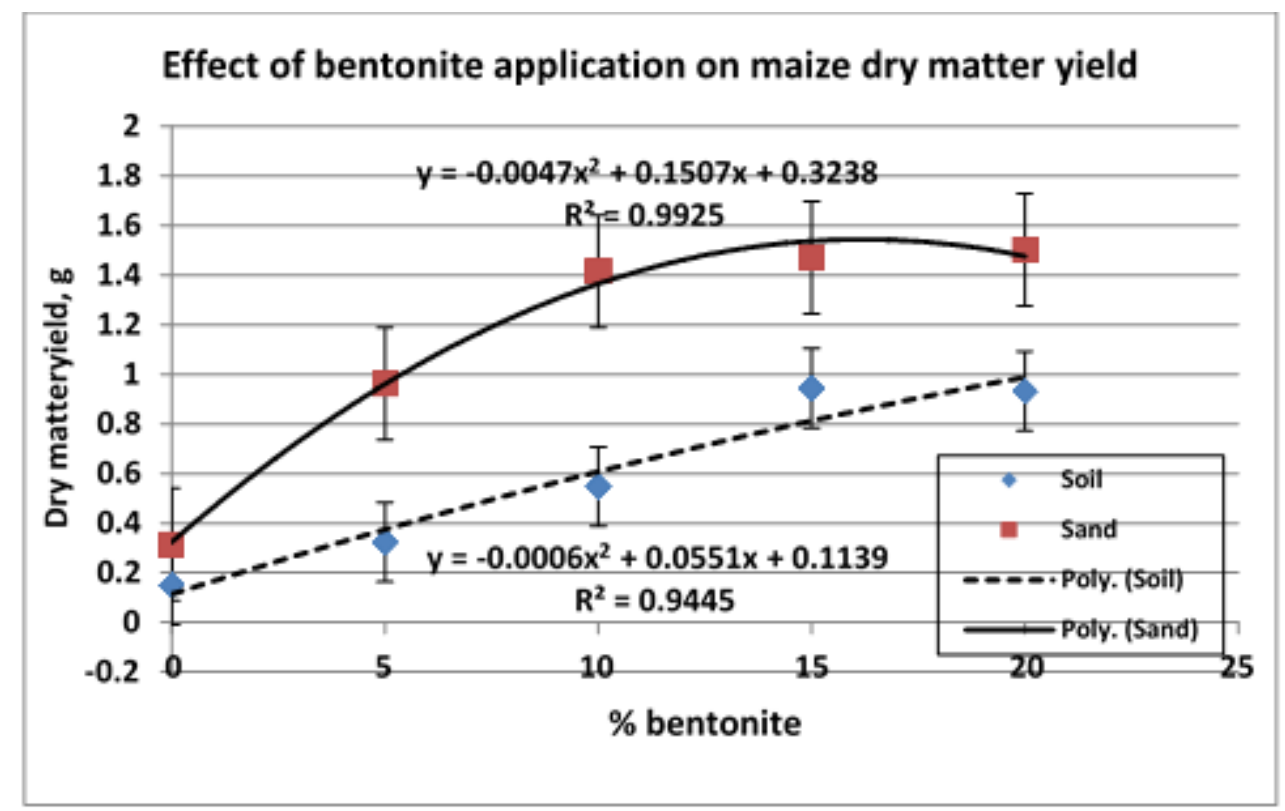

Figure 2. Effect of bentonite application on dry matter yield on two soil types in Uganda

Table 3. Effect of calcium bentonite application on maize grain yield, 2013

\begin{tabular}{|c|c|c|c|}
\hline \multirow[t]{2}{*}{ Treatment } & $2013 \mathrm{~A}$ & 2013B & $\begin{array}{l}2 \text {-season } \\
\text { average }\end{array}$ \\
\hline & \multicolumn{3}{|c|}{ — Yield $\left(\mathrm{kg} \mathrm{ha}^{-1}\right)$} \\
\hline Control & 660 & 718 & 689 \\
\hline Bentonite $\left(2.5 \mathrm{tha}^{-1}\right)$ & 591 & 1306 & 948 \\
\hline Bentonite $\left(2.5 \mathrm{tha}^{-1}\right)+$ DAP $\left(62.5 \mathrm{~kg} \mathrm{ha}^{-1}\right)$ & 656 & 1822 & 1239 \\
\hline Bentonite $\left(2.5 \mathrm{tha}^{-1}\right)+\mathrm{FYM}\left(2.5 \mathrm{tha}^{-1}\right)$ & 567 & 1941 & 1254 \\
\hline Bentonite $\left(1.25 \mathrm{tha}^{-1}\right)+\operatorname{DAP}\left(62.5 \mathrm{~kg} \mathrm{ha}^{-1}\right)+\mathrm{FYM}\left(1.25 \mathrm{t} \mathrm{ha}^{-1}\right)$ & 634 & 1541 & 1088 \\
\hline $\operatorname{DAP}\left(125 \mathrm{~kg} \mathrm{ha}^{-1}\right)+$ urea $\left(60 \mathrm{~kg} \mathrm{ha}^{-1}\right)$ & 713 & 2018 & 1365 \\
\hline Sed & 208.8 & 370.3 & 212.8 \\
\hline $\mathrm{CV}(\%)$ & 40.1 & 29.1 & 23.8 \\
\hline
\end{tabular}

combining bentonite with DAP or manure resulted in significant $(\mathrm{P}<0.05)$ increase in grain yields over the control.

\section{Discussion}

The sandy nature and low available nutrient status present management challenges, for sandy soils, some of which could be addressed through use of bentonite. Calcium bentonite had a higher $\mathrm{OM}, \mathrm{N}, \mathrm{P}, \mathrm{Ca}, \mathrm{Mg}$ and $\mathrm{K}$ content than all three soils materials. This suggests that bentonite application on such soils could possibly supply these limiting nutrients to these soils. The neutral $\mathrm{pH}$ suggests that 
if used in say acidic soil, bentonite will not acidify soil but assist in increasing soil $\mathrm{pH}$ to levels more suitable for most crop production. Compared to soil, sand material amended with calcium bentonite had higher moisture content, suggesting that bentonite application could improve moisture storage of sand and consequently improve its ability to support a growing crop. Bentonite application on sand significantly increased the $\mathrm{pH}, \mathrm{N}, \mathrm{P}, \mathrm{Ca}$ and $\mathrm{Mg}$ content. As a result, higher dry matter yields were observed from sandbentonite compared to soil-bentonite mixtures. The benefits were observed more on sand than on soil, suggesting that bentonite use could be more beneficial on highly sandy soils compared to medium textured soils. Sacchi (2010) reported increased soil cation exchange capacity, exchangeable $\mathrm{Ca}, \mathrm{Mg}, \mathrm{K}$ and plant available water following bentonite application.

Table 2 also shows that bentonite addition resulted in a decrease in the $\mathrm{Ca} /$ $\mathrm{Mg}$ ratio of both soil and sand, the trend increased with increasing rates of bentonite. This observation suggests that applying high rates of calcium bentonite could result into a $\mathrm{Ca}-\mathrm{Mg}$ imbalance compared to that of natural soils. Furthermore, bentonite rates higher than $10 \%$ on sand did not result into any further increments in biomass yield (Fig. 2). In addition, with increasing time of incubation, caking was observed especially in the soil mixtures containing 15 and $20 \%$ bentonite making them hard and increasingly difficult to sample. This observation suggests increasing resistance to root penetration at higher rates of bentonite. Thus, it is possible that rates higher than $10 \%$ bentonite somehow affected the soil (e.g. reduced soil moisture, $\mathrm{Ca} / \mathrm{Mg}$ ratio and increased soil caking which affected root development). A combination of these factors possibly resulted in a decrease in dry matter yield. This finding suggests that calcium bentonite should not be applied at rates higher than 10\%. In Australia, Sacchi (2010) observed that application of bentonite at rates of above $80 \mathrm{t} \mathrm{ha}^{-1}$ had a detrimental impact on soil structure leading to reduced yields. The current study points to reduced soil moisture and changes in soil physical and chemical properties when /if high rates of calcium bentonite are applied.

From this study, it is clear that bentonite use increased maize grain yields but with visible seasonal variations in its benefits. During the better 2013B season, applying bentonite alone resulted in up to $81.9 \%$ increase in maize grain yield. However, averaged over two sesaons, bentonite application resulted in $37.6 \%$ increase in grain yield, and up to 57.9 to $82.0 \%$ increase in grain yield where it was combined with DAP and/or FYM. These results are consistent with those of Noble et al. (2004) and Suzuki et al. (2007) who demonstrated that introducing clay-based materials such as bentonite significantly and persistently improves the productivity of degraded, light-textured soils, more so in the presence of an organic amendment. In similar experiments, application of 1.2 $\mathrm{t} \mathrm{ha}^{-1}$ bentonite increased rice grain yields by $73 \%$ and reduced the risk of crop failure during drought (IWMI, 2010). In another experiment sorghum forage biomass yields increased by six-fold following bentonite application and the improved soil quality was reported to have persisted for at least 3 years (IWMI, 2010). From a review of results from field experiments to assess the efficacy of bentonite addition on crop productivity and soil nutrient status, Berthelsen et al. (2005) reported significant increase in crop 
biomass and yields following bentonite application on light textured soils. The yield increase was attributed to a combination of increased water holding capacity, nutrient availability and reduced nutrient loss.

\section{Conclusion}

Amendment of a sandy soil with calcium bentonite significantly increases soil moisture, $\mathrm{pH}, \mathrm{N}, \mathrm{P}, \mathrm{Ca}$ and $\mathrm{Mg}$ content, and consequently, maize dry matter and grain yields. These benefits are greater on sandy soils than medium textured soils. For greenhouse work, the bentonite to sandy soil ratio in the mixture should not exceed $15 \%$. For field application on maize, bentonite should be applied at $2.5 \mathrm{t}$ $\mathrm{ha}^{-1}$ and combined with $62.5 \mathrm{~kg}^{\mathrm{DAP}} \mathrm{ha}^{-1}$ or $2.5 \mathrm{t} \mathrm{FYM} \mathrm{ha}^{-1}$. Results suggest increased chances of crop survival, following bentonite use on sandy soils under drought/ moisture stressed environments. Thus, bentonite use can be a promising technology for improving the productivity of sandy soils in the drought stricken/prone cattle corridor areas of Uganda. It is also a promising climate change adaptation technology. However more field studies are required to cover a wide range of crops, including profitability assessment.

\section{Acknowledgement}

This work was funded by the Agricultural Technology and Agribusiness Advisory Services (ATAAS)/Sustainable Land Management (SLM) project of the National Agricultural Research Organization (NARO). We are grateful for the technical support and guidance offered by the NARO management, and the Director, management and staff of NARL.

\section{References}

Berthelsen, S., Noble, A.D., Ruaysoongnerm, A.S., Webb Huan Hengfu, M. and Yi Jiexiang. 2005. Addition of clay based soil ameliorants to light textured soils to reduce nutrient loss and increase crop productivity. Conference Proceedings. Management of tropical sandy soils for sustainable agriculture. A holistic approach for sustainable development of problem soils in the tropics. $27^{\text {th }}$ Nov. $-2^{\text {nd }}$ Dec. 2005. KhonKaen, Thailand. FAO Corporate Document Repository. http://www.fao.org/docrep/010/ ag125e/AG125E00.htm

GOU. 2004. Increasing incomes through exports: A Plan for Zonal Agricultural Production, Agro-Processing and Marketing. Kampala, Uganda.

Czaban, J., Siebielec, G., Czy ¿, E. and Nied Ÿwiecki, J. 2013. Effects of Bentonite addition on sandy soil chemistry in a long-term plot experiment (I); Effect on organic carbon and total nitrogen. Pol. J. Environ. Stud. 22(6):1661-1667.

IWMI. 2010. Improving soils and boosting yields in Thailand. Success Stories. Issue 2 - 2010. www.iwmi.org/ Research Impacts/Impact Assessment/Outcome Stories/2008/ Bentonite $\% 20$ clays- $\% 20$ edited $\% 20$ outcome\%20story_final\%20_Web_.pdf

Mehlich, A. 1984. Mehlich No. 3. Soil test extractant: A Modification of Mehlich No. 2. Extractant. Commun. Soil Sci. Plant Anal. 15:1409-1416.

Mugisha, J., Diiro, G., Ekere, W., Langyintuo, A. and Mwangi. W. 2011. 
Characterization of Maize Producing Households in Nakasongola and Soroti Districts in Uganda. Country Report - Uganda. Nairobi: CIMMYT.

Noble, A.D., Ruaysoongnern, S., Penning de Vries, F.W.T., Hartmann, C. and Webb, M.J. 2004. Enhancing the agronomic productivity of degraded soils in North-east Thailand through clay-based interventions. In: Seng, V., Craswell, E., Fukai, S. and Fischer, K. (Eds.), Water and Agriculture, Proceedings No. 116, ACIAR, Canberra. pp. 147-160.

Rwabwoogo, M.O. 2002. Uganda Districts Information Handbook.
Fountain Publishers Ltd. (5 $5^{\text {th }}$ Ed.). Kampala, Uganda.

Sacchi, A. 2010. Improving the cation retention capacity of Tropical soils using high activity clays. James Cook University, Australia.

Suzuki, Shinji, Noble, Andrew, Ruaysoongnern, Sawaeng and Chinabut, Narong. 2007. Improvement in water-holding capacity and structural stability of a sandy soil in Northeast Thailand. Arid Land Research and Management 21: 37. doi: $10.1080 / 15324980601087430$ 